\title{
Reducing automotive emissions-The potentials of combustion engine technologies and the power of policy
}

\author{
Christian Berggren and Thomas Magnusson
}

\section{Linköping University Post Print}

N.B.: When citing this work, cite the original article.

Original Publication:

Christian Berggren and Thomas Magnusson, Reducing automotive emissions-The potentials of combustion engine technologies and the power of policy, 2012, Energy Policy, (41), 636643.

http://dx.doi.org/10.1016/j.enpol.2011.11.025

Copyright: Elsevier http://www.elsevier.com/

Postprint available at: Linköping University Electronic Press

http://urn.kb.se/resolve?urn=urn:nbn:se:liu:diva-76626 
Reducing automotive emissions - The potentials of combustion engine technologies and the power of policy 


\begin{abstract}
Reducing transport emissions, in particular vehicular emissions, is a key element for mitigating the risks of climate change. In much of the academic and public discourse the focus has been on alternative vehicle technologies and fuels (e.g. electric cars, fuel cells and hydrogen), whereas vehicles based on internal combustion engines have been perceived as close to their development limits. This paper offers a different perspective by demonstrating the accelerated improvement processes taking place in established combustion technologies as a result of a new competition between manufacturers and technologies, encouraged both by more stringent EU legislation and new CAFE levels in the US. The short-term perspective is complemented by an analysis of future improvement potentials in internal combustion technologies, which may be realized if efficient regulation is in place. Based on a comparison of four different regulatory approaches, the paper identifies the need for a long-term technology-neutral framework with stepwise increasing stringencies, arguing that this will encourage continual innovation and diffusion in the most effective way.
\end{abstract}

Keywords: Automotive emissions, internal combustion engines, S-curves, regulation, clean air act amendment, Euro 1- 6. 


\section{Introduction}

In 2010 the global population of cars, trucks and buses totalled one billion vehicles; in 2035 it is expected to reach two billions - and continue to grow (Sperling and Gordon, 2009: 5). Only to stabilize global $\mathrm{CO}_{2}$ emissions at the current level requires a 50\% reduction in average emissions per vehicle in the next 25 years. Whereas overall $\mathrm{CO}_{2}$ emissions in the EU-15 fell by $6.5 \%$ 1990-2008, emissions from road transportation increased by $21 \%$ (EEA, 2010). The challenge to reverse this process and start reducing road transport emissions poses critical questions concerning the potentials of various technologies, and how to design effective regulation.

The scientific debate has witnessed a strong interest in alternative automotive powertrains (Hekkert and van den Hoed, 2006; Suppes, 2006; Schoots et al., 2010) and optimistic scenarios about their market diffusion and cost reduction (Offer et al., 2010; Thiel et al., 2010). With few exceptions (Taylor, 2008), the interest in vehicles based on internal combustion engines (ICE) has been low, and the projections of their improvement potential pessimistic (Fontaras and Samaras, 2010; Zervas, 2010). Historical studies, however, suggest caution regarding the rates of penetration and diffusion of alternative technologies (Kromer et al., 2010). Incremental refinements of established technologies and modular innovations tend to be significantly lower in cost and also diffuse more rapidly (Schäfer et al., 2006). Furthermore, the introduction of new technologies accelerates the development of established ones, both by introducing a spirit of technological competition and by offering new combinative possibilities.

This paper investigates the continual improvement potential of ICE power-trains, and discusses the effectiveness of different regulatory approaches in further reducing 
automotive $\mathrm{CO}_{2}$ emissions. Rather than extrapolating trends from previous periods of stability, the paper focuses on the dynamics driving development in the current "era of ferment" (Anderson and Tushman, 1990; Magnusson \& Berggren, 2011), characterized by uncertainty, expanding technological opportunities, tightening regulation and increasing $R \& D$ investments. Since the extent of improvement possibilities in current technologies tends to be masked by industry averages, the paper - after an overview of recent trends - presents a case study of the redesign efforts in at a previously highemitting firm. This is followed by a section on further emission reduction potentials in ICE-vehicles, building on published technical reports and interviews with automotive $R \& D$ managers. The final sections on different types of regulation emphasize the importance for policymakers to learn from the recent European history of stepwise reducing noxious diesel emissions, to design a stringent, technology-neutral framework which can drive a broad diffusion of low-emitting vehicles in a cost-effective way.

\section{S-curves, competitive dynamics and accelerated improvement}

In an analysis based on simulated "typical vehicles" in the next 5-10 years, Fontaras and Samaras (2010:1832) arrive at pessimistic conclusions: "conventional power trains are already being pushed to their limits as indicated by the last 4 years' /2003-07/ almost zero improvement in diesel vehicle $\mathrm{CO}_{2}$ emissions". The paper forecast that a reduction of average $\mathrm{CO}_{2}$ emissions from the 2007 level to $130 \mathrm{~g} / \mathrm{km}$ or lower in 2015 , as required by EU regulation, is unlikely, and that it "is extremely difficult considering the present status" to reach the next indicated target, $95 \mathrm{~g} / \mathrm{km}$ in 2020 . Already in 2008 , however, both petrol and diesel cars in Europe refuted the idea of "being pushed to their limits" by 
making a more rapid progress than in the previous ten years, and in 2009 average emissions fell by a further $5.1 \%$ (Transport \& Environment, 2010). The financial crisis and the scrappage schemes made this a special year, but the majority of the reductions were related to better technology and not to a change to smaller cars, and in 2010 emissions from new cars fell by a further $4 \%$ to an average of $140 \mathrm{~g} \mathrm{CO}_{2} / \mathrm{km}$ (Transport \& Environment, 2011). Whereas it previously took ten years from 1998 to 2007 for European cars to reduce their $\mathrm{CO}_{2}$ emissions by $22 \mathrm{~g} / \mathrm{km}$, manufacturers now needed only the three years from 2007 to 2010 , to cut them by a further $19 \mathrm{~g} / \mathrm{km}$. This illustrates the difficulty of using previous trends to predict technological limits without accounting for regulatory changes, which change the dynamics in the industry.

Forecasts based on historical patterns tend to subscribe to notions of industrial S-curves. Slow progress during a specific period is interpreted as a sign of the industry reaching the end of this curve, making further progress increasingly difficult and expensive. In his studies of the disk drive industry, however, Christensen found that there is normally not one single S-shaped curve (Christensen, 1992). When competition intensifies, by the introduction of different technologies or the advent of new entrants, repeated upward twists of the S-curve of established technologies occur, resulting in significant performance improvements with no distinct end points in sight. This analysis is highly relevant for the auto industry with its multitude of different technologies, each with its own development trajectory. New twists on the S-curve of established technologies are illustrated by the reduction of diesel engine emissions during the last 20 years (19922012), resulting in a 95\% elimination of noxious exhausts: "With Euro 6 we need to 
reduce NOx and particles to levels that seemed totally impossible 10 years ago and at the same time achieve good overall efficiency..." (Simmons, 2011). Rising to this challenge, truck makers started to launch vehicles with Euro 6-engines in spring 2011, two years ahead of binding legislation, and diesel cars are undergoing the same process.

Recently several factors have changed the competitive dynamics in the European car industry, such as the advent of competing technologies and architectures, mainly from Japan; the shift in the EU policy regime regarding $\mathrm{CO}_{2}$ emissions from voluntary agreements to binding regulation; and a quadrupling of oil prices from US \$20-30 in the 1990s to US \$90-120 in 2008-2011 (Brent crude oil; the latter period includes an episode of extreme volatility). To estimate the real-world potential for progress on the ICEtrajectory in this environment, it is important to study diversity at the firm level. Reports from Transport \& Environment (2009-2011) illustrate that differences between carmakers go far beyond those related to various segments and weights. The next section will use one particular case to explore these differences and analyze the potential of low-cost improvements in these established technologies. As a general measure of fuel efficiency and emissions we use the tests results using the New European Driving Cycle (NEDC). The test is performed in conditions simulating a flat road at $20-30^{\circ} \mathrm{C}$ and all ancillary loads are turned off (air conditioning compressor and fan, lights, heated rear window, etc); thus consumption and emissions differ considerably from real world driving. This applies to $\mathrm{CO}_{2}$ emissions, but even more to NOx emissions (Tzirakis, et al. 2006), an increasing problem with the diffusion of cars propelled by direct injection engines operating at higher loads. Similar test cycle limitations apply to alternatively powered 
vehicles, e.g. electric cars, where efficiency and range are strongly influenced by the use of air condition systems and the calculations of emissions is impacted by the specific energy mix in the power generation system. With all their deficiencies, the NEDC-results are the best available measures to compare $\mathrm{CO}_{2}$ emissions of different car models in Europe, as well as change over time. For regulators it is a challenging task to establish more realistic test cycles which cover the increased variation of technologies.

\section{Competitive repositioning - the case of Volvo DRIVe}

To comply with the EU greenhouse gas emissions regulation, several automakers have launched special lines of low emitting models, such as BlueMotion at VW, BlueEfficiency at Mercedes-Benz, Econetic at Ford, Efficient Dynamics at BMW and DRIVe at Volvo. In the 2007-2010-period, these best practice models achieved a $\mathrm{CO}_{2}$ emissions reduction between 20 and 30\% compared to equivalent standard models (Transport \& Environment, 2010: 26). By means of a case study at one manufacturer, Volvo Cars, this section explores how the new competition forced accelerated progress and change in long established patterns.

Prior to 2007, R\&D at Volvo Cars had focused on spacious family cars, in the late 1990s extended to include "sportiness" and US-style SUVs. This resulted in fuel consumption significantly above the EU average. High fuel consumption also characterized average vehicles on the company's home market, Sweden, which reported the highest average vehicle emissions in the EU (Transport \& Environment, 2007). Swedish politicians reinforced this pattern by subsidizing so-called flexi-fuel cars, even if they emitted more 
than $200 \mathrm{~g} \mathrm{CO}_{2} / \mathrm{km}$ when driving on gasoline (Kågeson, 2009). When competitors started to launch low-emitting models, Volvo had little to offer and few projects in the pipeline. In order to show at least something at the important Frankfurt auto show in 2007, top management asked the R\&D unit for special vehicles to reconfigure the company's smallest model, C30, and present it as an "eco-car". A team of experienced engineers took the initiative and without waiting for formal decisions, they initiated a broad reengineering campaign labeled "DRIVe". They simplified the product development process, included rapid interaction with regulatory authorities, and reduced costs and test time by systematically using established technologies (VCC, 2010a). After one year, production started of the first DRIVe versions of Volvo's compact cars, S40 and V50, with emissions at $119 \mathrm{~g} \mathrm{CO}_{2} / \mathrm{km}$. Six months later, more advanced versions had reduced emissions to $104 \mathrm{~g} / \mathrm{km}$. DRIVe versions of the larger models followed, and in 2009 Volvo could offer lower emitting versions of seven of its nine European models. Early in 2010, production started of an improved version of the large V70 DRIVe model with fuel consumption at $4.5 \mathrm{l} / 100 \mathrm{~km}$ and $\mathrm{CO}_{2}$ emissions reduced to $119 \mathrm{~g} / \mathrm{km}$. Two years earlier the most efficient version of this model had consumed $6.0 \mathrm{l} / 100 \mathrm{~km}$. Later in 2010, improved versions S40 and V50 reported emissions at $99 \mathrm{~g} / \mathrm{km}$. All these cars were powered by diesel engines and therefore not marketed in the US. See Table 1.

Table 1.

Emissions of Volvo DRIVe models in 2010 and corresponding best models in 2007.

$\begin{array}{llll} & \text { DRIVe 2010 } & \text { Best model 2007 } & \text { Improvement (\%) } \\ \mathrm{C} 30 & 99 \mathrm{~g} / \mathrm{km} & 129 \mathrm{~g} / \mathrm{km} & 23 \\ \mathrm{~S} 40 & 99 \mathrm{~g} / \mathrm{km} & 129 \mathrm{~g} / \mathrm{km} & 23\end{array}$


V50

V70

S80

XC60

$\mathrm{XC70}$

$$
99 \mathrm{~g} / \mathrm{km}
$$$$
119 \mathrm{~g} / \mathrm{km}
$$$$
119 \mathrm{~g} / \mathrm{km}
$$$$
154 \mathrm{~g} / \mathrm{km}
$$

$159 \mathrm{~g} / \mathrm{km}$

Average, non-weighted, rate of improvements
$132 \mathrm{~g} / \mathrm{km}$

$157 \mathrm{~g} / \mathrm{km}$

25

$167 \mathrm{~g} / \mathrm{km}$

186 g/km (2008, new model)

$193 \mathrm{~g} / \mathrm{km}$

18

$23 \%$

Source: www.alltommotor.se/bildata 20100505, VCC 2010b

With a constrained time and budget in a bleeding company, Volvo's key to success was not new technology, but a new overall performance parameter: $\mathrm{CO}_{2}$ emissions and fuel efficiency. This meant trading off some power and acceleration. All the cars with emissions lower than $120 \mathrm{~g} / \mathrm{km}$ are built around a 1.6 liter turbocharged diesel engine, a considerable downsizing for the larger models. By doing so, Volvo engineers utilized the accumulated results of the long process of European diesel engine development since the 1980s (Berggren et al., 2009). The total vehicle package included other modifications, such as optimized engine control software, adapted gear ratios, low-friction tires, and streamlined body details and chassis to reduce drag. In the second step, the smaller cars achieved $99 \mathrm{~g} / \mathrm{km}$ by means of an adapted stop/start system. In the larger cars, changes were also implemented in the power train's auxiliary systems, such as electric power steering and optimized battery charging, whereby the alternator charges the battery when the engine is operating at low capacity. According to a comparative analysis of the performance of EU carmakers in reducing $\mathrm{CO}_{2}$, Volvo delivered the largest cuts in 2010, with a 9\% reduction on average (Transport \& Environment, 2011). 
At the time of their first announcement in 2008, Volvo product planners estimated the DRIVe versions to account for $10 \%$ of its European sales. The outcome turned out to be four times higher with the low-emitting models accounting for 39\% of all Volvo cars sold in Europe (Q1-Q3 2010), and 47-60\% of the compact cars (VCC, 2010c). In Belgium, special incentives such as a $15 \%$ reduction of the purchasing price for vehicles that emit less than $105 \mathrm{~g} / \mathrm{km}$ (ACEA, 2010), made Volvo's low emitting models particularly popular. With the DRIVe line, Volvo also showed that emissions from large cars, such as S80, can be reduced below the EU target at a very limited time and cost. But with customers traditionally preferring powerful engines, the commercial success of fuelefficient versions of Volvo's largest cars was modest.

\section{ICE development, near- and mid-term improvement potentials}

"Increasing levels of vehicle electrification will help extend the ICE's life." (Ford, Director of Power train Research, in Kapp, 2010). Whereas some analysts argue that the reduction of $\mathrm{CO}_{2}$ emissions from conventional passenger cars is reaching its limits, Volvo DRIVe managers contend that their large V70 model can reach a fuel consumption of $3.5 \mathrm{l} / 100 \mathrm{~km}$ (below the long term $\mathrm{EU} \mathrm{CO}_{2}$ emissions target of $95 \mathrm{~g} / \mathrm{km}$ ) within the next few years. This would amount to a $40 \%$ reduction compared to the best model in 2008. An important reason for this confidence is the increasing electrification of auxiliary systems and the new opportunities in engine management systems. Moreover, in spite of recent improvements, the combustion engine is far from a plateau in its development. The following section presents an overview of near-term or on-going improvements. 
Thereafter some examples of long-term improvement potentials in ICE-based power trains are discussed.

\subsection{Near-term efficiencies in ICE-based vehicles}

The examples below are already introduced on the market or announced for the next few years (approximately 2011-2015 or one development cycle). The list does not exhaust the possibilities. A continual part of ICE development, for example, is to reduce friction losses by improvements in lubrication, surface materials and optimization of moving components.

\section{Improvements in auxiliary engine systems}

High-efficiency generators reduce the losses in existing electrical equipment. Mechanical and hydraulic systems are replaced by electrical equipment, and on-demand operation replaces continuous operation, thus reducing parasitic losses (EPA, 2010). This changeover is diffusing broadly among manufacturers; Ford has announced that $90 \%$ of its vehicles will be equipped by electric power steering in 2012 , to save several per cents in fuel consumption (Kranz, 2009). LED-lights as announced by German premium makers will replace conventional halogen lighting, and save another 1-2\%.

\section{Improvements in air conditioning-systems}

A modern car contains a multitude of off-cycle loads that can be switched on by the driver. The most important of them, the AC-systems, are responsible for $4 \%$ of vehicular $\mathrm{CO}_{2}$ emissions in the US (EPA, 2010: D-6). Significant reductions can be achieved by 
replacing conventional air compressors with improved electrical systems and reduced leakage of coolants.

Improvements in transmissions: multi-speed gearboxes and dual clutch transmissions Five-speed gearboxes are replaced by multi-speed gearboxes, beginning with six-speeds in mass market cars (i.e., Ford and Volkswagen). Seven- to eight-speeds are already offered by premium makers. At the same time, dual clutch transmissions replace torque converters and make automatic transmissions at least as efficient as manual (Moran, 2010). The British King report projects $4-5 \%$ improved efficiency by means of dual clutch transmission (King, 2007), while US EPA (2010: B14) states that a six-speed gearbox with dual clutch may improve efficiency $10-15 \%$ compared to a four-speed conventional automatic.

\section{Micro-hybridisation}

Start-stop systems using belt-driven starter-alternators are currently being offered as an option by almost all European vehicle makers. These systems can be expanded to additional driving situations; for example the Stop In Neutral (SIN) approach tested at Volvo Cars, which according to its engineers may reduce fuel consumption up to $15 \%$ : "gravitational force is the most cost-effective hybrid solution" (VCC, 2010b). Real fuel savings and emissions reduction heavily depend on actual driving cycles and independent assessments of general start-stop systems are more cautious, stating that savings of 3-4\% is a realistic short-term prognosis (King, 2007). 
Reduction of pumping losses by advanced valve management systems

Combustion engines can improve considerably if air intake and air-fuel ratios are optimized over a wider operating range (Knight, 2010; EPA, 2010). For several years, automakers have offered systems to continuously alter valve timing, lift, and duration. In 2009-2010, BMW launched engines combining compact valve management systems with direct injection and turbo charging. In 2010, FIAT offered a variable valve actuation technology with no throttle valve, "Multi-air", which according to the company reduces emissions by up to $10 \%$.

\section{Downsized turbo charged engines with improved operating load}

A key problem in combustion engines is the huge gap between maximum power and normal operating load (Johansson, 2010). Theoretically this could be reduced by variable cylinder volume; the industrial approach so far is downsizing, direct injection and turbo charging. By approximating volume variability, turbo charging makes ICE-engines more efficient at normal load conditions; sequential turbo with variable geometries reduces the gap further (Knecht, 2008). This can result in fuel savings of 10-15\% (King, 2007). More advanced turbo charging includes cooled exhaust gas recirculation (EGR). According to estimates by Ricardo Engineering, cooled EGR combined with engine downsizing, single-stage turbo charging, and valve timing management reduces $\mathrm{CO}_{2}$ emissions by 23\% (EPA, 2010: B-11). In the US, downsizing has started from V8 to V6, and V6 to 4cylinder engines. In Europe the trend is downwards from 4-cylinder engines, such as the VW Polo 3-cylinder diesel (Lilja, 2009) or Fiat 500 with its 2-cylinder 0.9 liter gasoline engine (Crank Motoring, 2010). 


\subsection{Longer-term, 2015-2025 (two-three development cycles)}

\section{Micro-hybridisation(II) and kinetic energy recovery}

Higher voltage-systems in conventional vehicles increase the possibilities of regenerative braking, and extend auxiliary systems electrification (EPA, 2010: 3-25). KERS, kinetic energy recovery systems, are another road to regenerative braking, which Volvo started to test in 2011, using a new carbon flywheel technology. Flywheels are more power dense than batteries and can deliver energy very rapidly which makes the technology highly responsive. According to Volvo Powertrain Engineering, the technology is cheaper than full-blown hybrid systems and if tests are positive "could reach showroom floors in a few years" (Ashley, 2011).

\section{Optimization of the combustion process}

Combustion process development is confronted with two conflicting problems: minimize fuel consumption, and eliminate noxious gases and pollutants. For gasoline engines, the three-way catalyst basically solved the second challenge, but the problem how to reduce fuel consumption remained. Diesel engines are more fuel-efficient than gasoline engines, but need complex auxiliary systems to eliminate local pollutants. In the US, gasoline engines completely dominate the light duty vehicle fleet, and neither automakers nor regulators have seen this as a problem. In Europe, with historically higher fuel taxes and stronger focus on fuel efficiency, automakers and regulators have been more interested in ways to make diesel engines cope with both demands. These efforts have led to 
significant improvements in combustion diagnostics, sensors, electronic control and engine management systems (Knecht, 2008; Bauner, 2007), but at the expense of adding costly after-treatment systems. To solve the dual problems of pollution and efficiency, researchers study new types of combustion processes, which combine improved thermodynamic properties and thus higher efficiency, with the low levels of pollutants emitted from modern gasoline engines. For a long time the so-called HCCI-engine (homogeneous charged compression ignition) seemed to be the most promising avenue; but several difficult obstacles (Taylor, 2008) reoriented research towards modified processes termed PPC (partially premixed combustion). According to researchers in this field, a PPC-engine could achieve almost double the efficiency of a conventional gasoline engine (Johansson, 2010). In modern diesel management systems, PPC-principles are already implemented in part-load operation. But before being possible to implement in all load conditions, injections systems need to be fine-tuned and comprehensively tested, and fuelling principles need to be reconsidered. One alternative is to use gasoline in diesel engines, another is to use dual fuel, with diesel for part load and gasoline for full load (Dunbeck and Reitz, 2010; Lewander et al., 2009; Manente et al., 2010a, 2010b; Ra et al., 2009).

\section{Waste heat recovery}

Another long-term area for efficiency improvement is recovery of energy from exhaust heat, which represents approximately $30 \%$ of the energy input in an internal combustion engine (Taylor, 2008). Turbo charging is a first step, dual stage turbo charging with advanced exhaust gas recovery a second. Other steps include turbo compound, where 
more exhaust gas energy is recovered, or coupling of a turbo-charger with an electric motor /generator to reduce fuel consumption and turbo-lag (Knecht, 2008). The efficiency of these devices is related to specific driving cycles and turbo compound has only been introduced in heavy duty trucks in specific segments. More exhaust energy can be utilized in a Rankine cycle, where exhaust heat feeds into a steam generator to generate power, which is used to charge the vehicle's electrical systems. Several automakers have announced R\&D activities in different thermoelectric devices, including BMW, GM and Ford (DoE, 2009).

This overview of ICE-based improvement possibilities raises the question of limits to such efficiency increase. From a purely theoretical perspective, with no constraints on motion or costs, there is no limit. The more interesting question concerns the practical limits for mass market vehicles. Rules of thumbs used by ICE-researchers indicate a vast untapped potential: a factor of two in efficiency to be gained for gasoline fueled SI engines (i.e., from $\sim 30 \%$ to $60 \%$ ), and another factor of two in propulsion efficiency of a specified vehicle (Edwards, 2011).

\section{A comparison of different pathways}

The joint report by EPA, CARB and NHTSA (EPA, 2010) evaluated four possible technology pathways for the 2017-2025 model years: one mainly based on advanced gasoline engine technologies, another relied on penetration of hybrid electric vehicles, a third was based on more advanced hybrids and electrified cars, and a fourth somewhere in between. The report assessed these pathways in relation to various stringency levels in 
$\mathrm{CO}_{2}$ emissions regulation for 2017-2025; the lowest requiring 3\% and the highest $6 \%$ annual reductions. With the highest stringency level, emissions from new US cars in 2025 would average $143 \mathrm{~g} / \mathrm{mile}$, approximately $89 \mathrm{~g} / \mathrm{km}$. For all levels the result was the same: "The conventional vehicle technologies are typically more cost effective than any of the other technology options" (EPA, 2010: 6-14). When upstream processes such as electric power generation and distribution were included, the ICE-based pathway (including a substantial portion of hybrid vehicles in the most demanding reduction scenario) tended to be superior also in terms of $\mathrm{CO}_{2}$ emissions. Life cycle emissions for electric vehicles differ considerably between countries, however, depending on the $\mathrm{CO}_{2}$ intensity of the power generation mix. By simulating the performance of equivalently specified EVs and ICE-vehicles, Doucette \& McCulloch (2011) found that in countries with low carbon intensity in the power generation system, electric vehicles were vastly superior in terms of emissions. However, in the US with its heavy use of coal as feedstock for electric power generation, EVs were only slightly better; and in countries such as China and India with very high carbon intensity in their power production, the overall emissions of the most efficient diesel cars were equal to or lower than those for corresponding electric vehicles. As demonstrated above, ICEs have a significant potential to further reduce losses and emissions, whereas the losses in motors propelling electrical vehicles are already at a very low level. In countries with high carbon intensity which fail to change the energy mix in their power production, the emissions advantage of the ICE will increase if its improvement potential is realized.

\section{Fuel price versus regulation}


The increase in oil prices during the last ten years, and the prospect of even higher prices on the back of rising demand in emerging economies, the stagnation in crude oil production, and the need to use more expensive unconventional oil (IEA, 2010) are important factors influencing long-term planning at automakers. Consumer decisions, however, tend to be less influenced by oil prices. According to EPA calculations, the added cost per vehicle in 2025 for its most aggressive emissions reduction scenario would have a consumer payback period of only 3.1 years (EPA, 2010: 6-14, 6-17). Studies of consumer behavior (Greene, 2010), point out that such a payback period is insufficient to drive a market-based penetration of fuel saving technologies. Based on a broad comparison of the effects of regulatory standards versus prices on automobile fuel economy, Clerides and Zachariadis (2008:268) argue that: "Fuel prices do play a role in reducing fuel consumption but the price elasticity is quite small even in the long run, so that it becomes difficult to improve fuel efficiency considerably relying on prices increases alone". By contrast, they found that regulation continued to drive improvements also when prices were falling, as long as stringencies were increased. In the US case, fuel price increases had somewhat more impact than in Europe, which could be related to its higher average fuel consumption. Conversely, this means that as cars become more efficient, fuel price increases have less impact and regulation will be more important to drive further efficiencies. This brings us to the next section.

\section{Experience of automotive emissions regulation in Europe and the US}

For a long time the automotive industry in the OECD-countries has been heavily regulated in many aspects, including emissions. Therefore the impact of different types of 
regulatory approaches can be compared. Below four different models of regulation will be discussed and related to the challenge of $\mathrm{CO}_{2}$ emissions reduction.

1. Technology-forcing at a modular level: The US emissions control legislation (HC, CO, NOx) 1970-2000.

2. Radical technology-forcing at an architectural level: California's ZEV-mandates in the 1990s.

3. Voluntary agreements: The European experience of $\mathrm{CO}_{2}$ emissions reductions by voluntary industry agreements 1998-2008.

4. Stepwise reduction over a protracted period: The European emissions regulation (NOx, PM, CO) 1992 to 2013-14.

\subsection{Technology-forcing at a modular level}

After a period of escalating criticism of automotive emissions and mounting political pressure (Tao et al., 2010), US Congress introduced the path-breaking Clean Air Amendment Act, CAAA, in 1970. Following this law, EPA required that by 1975, the industry should reduce HC and CO emissions by $90 \%$ compared to the levels in 1970 , and in the following year cut also NOx emissions by $90 \%$. Initially the legislation met strong resistance; various executives argued that the reduction requirement "could prevent continued production of automobiles" and would "do irreparable damage to the American economy" (quoted in Lee at al., 2010: 260). The tight deadlines were postponed to 1980-81, but the targets largely remained in place. In 1990 the Congress took another step by introducing the Tier I-standard, followed in 1999 by the Tier II-level 
to be phased in 2004-09. Compared to the levels before the first CAAA, this standard mandated a reduction of $\mathrm{HC}$ and $\mathrm{CO}$ emissions of $98 \%$ and $95 \%$, respectively. This would not have happened by the industry's own efforts, and could not have been forecast by simulations based on technology trends in the 1960s. A detailed study by Lee et al. (2010) shows how the industry responded by increasing its R\&D, indicated by patenting in emissions control technologies; from virtually none in1970 to almost 100 patents granted annually in the mid 1970s. When the stringency level was unchanged in the 1980 s, the R\&D quickly subsided. However, when new more stringent standards were announced and introduced in the 1990 s, the activity increased to new heights. Now the system integrators, the car companies, had become the innovation leaders. Technology-forcing has been criticized for being costly and obstructing innovations not foreseen by the legislators (Jaffe et al., 2002). However, this emissions legislation was a major success, both in terms of air quality and automotive innovation. One reason was the competence and credibility of the regulatory agencies (Gerard and Lave, 2005); another was the consistent efforts of these agencies to encourage competition by inviting firms outside the industry such as the specialty chemical firm Johnson Matthey for catalyst development; a third was the possibilities opened up by the technological advancements that gradually transformed the engine from a mechanical machine to a mechatronic compound ${ }^{\text {a }}$. Regulatory agencies supported this development, diffusing information of innovations across the industry (Tao et al., 2010).

\footnotetext{
${ }^{\mathrm{a}}$ This insightful note was raised by an anonymous reviewer.
} 


\subsection{Radical technology-forcing at an architectural level}

California played a major role in the process of increasing the stringency of US federal automotive emissions regulation. Prompted by the success of these efforts, and the apparent availability of pollutions-free electrical vehicles demonstrated by GM (Shnayerson, 1996), Californian authorities introduced the so-called Zero-emission vehicle-rule in 1990. This regulation demanded an elimination of all hazardous tailpipe emissions, requiring automotive majors to introduce emission-free vehicles for a rapidly increasing part of their sales, 2\% in 1998, 5\% in 2001, and 10\% in 2003 (Sperling and Gordon, 2009: 188). The regulation inspired startup firms in the electrical vehicle field and collaboration between automotive and non-automotive companies to develop battery technologies (Pilkington and Dyerson, 2005). But the fundamental intention with the legislation - to enforce the conversion of the Californian vehicle fleet to zero-emitting vehicles - failed. Resistance from automotive companies resulted in repeated rounds of revisions of the ZEV mandate, and extended battles in court. In the early 2000s, the mandate had only resulted in a few thousand EVs and a few hundred fuel cell vehicles, to be compared with the annual sales of two million new cars in California (Sperling and Gordon, 2009).

\subsection{Reducing $\mathrm{CO}_{2}$ emissions by voluntary agreements?}

The US and in particularly California, were global pioneers in reducing polluting emissions from gasoline engines, belatedly followed by other countries (Bauner, 2007). In relation to $\mathrm{CO}_{2}$ emissions, the European Union has been at the forefront. Already in 1994, Germany proposed a target of $120 \mathrm{~g} \mathrm{CO}_{2} / \mathrm{km}$ at a meeting of environment 
ministers, and this target was formally announced in a European Commission communication one year later (Transport \& Environment, 2009:7). To avoid legislation, ACEA, The European Automobile Manufacturers Association, committed itself on behalf of its members to reduce average $\mathrm{CO}_{2}$ emissions from new cars to $140 \mathrm{~g} / \mathrm{km}$ by 2008 , a reduction of $25 \%$ compared to the level in 1995. A follow-up study, however, showed that the initial progress during the first years, mainly a result of a shift from gasoline to diesel cars, had leveled off at around $160 \mathrm{~g} / \mathrm{km}$. With virtually no progress from 2004 to 2006, ACEA was far from its espoused target (Transport \& Environment, 2007). The voluntary agreement approach could not counteract other market forces, leading to increased vehicle weight and size, and failed to trigger any competitive dynamics for reduced emissions.

\subsection{Stepwise reduction over a protracted period}

Shortly after US Congress passed its second major revision of the CAAA in 1990, the European Union began to implement a new framework for eliminating noxious vehicle emissions (NOx, PM, CO). This framework started with the EU 1 level in 1992,which was followed by gradually tightened standards through Euro 2 (1996), Euro 3 (2000), Euro 4 (2005), Euro 5 (2009) and Euro 6 in 2013-2014 (EC, 1998; EC, 2007). A corresponding system, denoted with the Roman figures Euro I to Euro VI, regulates emissions from heavy vehicles. For gasoline cars, the first three steps in this regulation implied few stringency increases. Euro 4 required a reduction of $\mathrm{CO}, \mathrm{HC}$ and NOx emissions of approximately 50\%, but thereafter the level has been stable. Diesel engines encountered tougher demands. The steps from Euro 1 to Euro 3 required a reduction of 
$\mathrm{CO}, \mathrm{HC}+\mathrm{NOx}$, and $\mathrm{PM}$ emissions by $42-76 \%$. Euro 4 stipulated another $50 \%$ reduction in NOx and PM emissions; and from Euro 4 in 2005 to the last step, Euro 6 in 2013/14, diesel vehicles are required to reduce NOx and PM by another $70 \%$ and $90 \%$, respectively. Efforts to comply with these requirements have consumed considerable $\mathrm{R} \& \mathrm{D}$ resources; according to estimates by truck producers in the range of $50 \%$ of all R\&D investments (Scania, 2008). These regulatory requirements have competed with efforts to reduce fuel consumption. This partially explains the observation that dieselpowered cars in some years failed to improve their fuel efficiency at the same rate as gasoline cars, which was misunderstood as a sign of diesel reaching its development limits (Zervas, 2010).

\subsection{Comparing the regulatory models}

The US examples of legislation both had a technology-forcing character, but at very different levels. The CAAA-regulation enforced the development of a new advanced component. This was a modular innovation (Henderson and Clark, 1990) which could be fitted to all vehicles equipped with modern injection and control systems. The ZEV-rule tried to enforce the market diffusion of an entirely new vehicle architecture. This could not be added to existing platforms, but implied the replacing of all existing power-train technologies. The mandate formulated market penetration in terms of a stepwise increasing stringency (percentage of annual sales). The new vehicles could not be developed and tested in any gradual way, however, but had to be introduced in one single package competing on cost, reliability and performance with conventional cars. 
Whereas the US CAAA has been extensively studied, the European Euro 1-6 emission regulation has been much less investigated. There are significant similarities as well as differences. Both implied modular additions and changes in existing vehicles (more expensive and complex in the diesel case, but still modular), and did not demand any alternative vehicle architectures. This resulted in a very rapid diffusion of the new technologies across vehicle fleets at the required dates. Several European countries accelerated this process by incentives to manufacturers which could market "clean" vehicles ahead of schedule. Further, the regulatory approaches consisted of several levels of increasing stringency. In the US there were basically three big steps, with a long time lag between the first and the second as a result of changing political majorities; in Europe there has been a more stable long-term system of steps with increasing stringency. Both of the approaches have been driving innovation; in the US case, catalyst technologies and electronic controls (Lee et al., 2010), in the European case, improvements in combustion diagnostics, sensors, electronic control, and management systems for diesel engines (Bauner, 2007; Knecht, 2008). The gradual tightening of standards, with each step implying a challenging but not impossible goal, has very much changed the perception of diesels in Europe, also within the industry: "If people had told us at the start that we would accomplish what we are actually doing today we would never have believed them!” (Engine \& emissions manager, Scania, 2007).

Compared to the American experience, the forcing elements of EU's diesel regulation have been less technology-specific. Another difference is that the Euro regulation seems to have had a more profound impact on industrial dynamics, by stimulating the 
competition between different ICE-based technologies. The enforced cleaning of diesel engines, combined with other improvements such as common rail injection systems, resulted in a boom for this engine technology in Europe and has spurred manufacturers to launch clean diesels as an alternative to hybrids in the US (Kurylko, 2010).

Of the four approaches to reduce automotive emissions analyzed here, two stand out as less successful: The non-forcing European voluntary agreement approach failed to commit individual companies and encourage any new innovative dynamics. The strongly forcing zero emissions vehicle-mandate in California failed in a different way: it did encourage innovations and entrepreneurship among auto firms and their suppliers, but not enough to bridge the huge technology gap to the required new solutions. The US federal and European regulatory systems to curb noxious tailpipe emissions have been considerably more successful. They both involved a process of several, increasingly stringent steps giving the industry an important long-term planning horizon (although the first American CAAA was very tight in this respect); they focused on development of modular systems which did not require new vehicle architectures; and they encouraged and forced innovation far beyond the rate of progress demonstrated by the industry before the legislations were announced.

\section{Conclusions: Reducing $\mathrm{CO}_{2}$ emissions by learning from previous}

\section{regulation}

To combat increasing $\mathrm{CO}_{2}$ emissions, governments both in the $\mathrm{EU}$ and the US have spent huge resources on specific new technologies, from batteries to fuel cell systems and 
introduced generous incentives to support the sales of electrified vehicles. In specific market segments, e.g. city commuting, electrical vehicles seem to have a chance to realize the much expected take-off. In growth economies such as China and India, increasing urban air pollution may stimulate an adoption of stringent standards for ICEemissions, but also accelerate their efforts to diffuse electrical vehicles. But outside metropolitan areas their limited range remains a severe handicap.

The previous sections have demonstrated the improvement potentials in the established ICE-based power train. New upward twists on its performance S-curve continue to occur when engineers exploit advancements in combustion research, electronics, material science and electrical engineering. The paper has illustrated how quickly these gains can be realized in existing car platforms when a vehicle maker is faced with the imminence of regulation and new competitive priorities. To reduce automotive $\mathrm{CO}_{2}$ emissions beyond 2012/15, the EU needs to build on its own regulatory history and make use of this expanding technology repertoire. Three general properties are important for such a regulation: to be effective in systematically driving down $\mathrm{CO}_{2}$ emissions; to be efficient in doing this, i.e., accomplish these results at the lowest possible cost; and to encourage broad innovation in the industry, irrespective of technological trajectories.

The efficiency and innovation aspects require a long-term framework, in line with the Euro 1-6 regulation, with increasingly stringent steps towards the goal of very low emitting vehicles. The $120-130 \mathrm{~g} / \mathrm{km}$ target to be phased in 2012/2015 is an important first step, and has already had a broad impact. A review in 2010 of the Swedish car 
market, previously notorious for its low fuel efficiency, identified almost 100 car models with emissions lower than this EU target, noting that in the compact class ("the Golf segment"), car makers just have to offer such models (Stjerna, 2010). However, as demonstrated by Lee et al. (2010) in their analysis of the American automotive emissions regulation 1970-1998, innovative initiatives among firms quickly subside if new, more stringent levels are not announced. Thus it is critical for EU regulatory authorities to make legally binding the next, lower, emissions level for 2020, such as the preliminarily announced $95 \mathrm{~g} / \mathrm{km}$ target to be reviewed by the Commission in 2013. Five-year intervals provide automakers with one full car-development cycle to comply with each new standard. Building on this rhythm and an ambitious scenario of 5-6\% annual reductions, as analyzed by EPA (2010), a new emissions level of 70-75 $\mathrm{g} / \mathrm{km}$ could be announced for 2025 , followed by $50-55 \mathrm{~g} / \mathrm{km}$ for 2030 . The 2020 target will be attainable for a majority of the vehicle fleet with improvements in ICE-based technologies as discussed above; the following steps will probably require some commercial breakthroughs for advanced combustion processes or increased electrification, or both. An expanding presence of technological alternatives could help lawmakers to maintain ambitious targets, although efforts from auto industry lobbyists to reduce future stringencies could be expected also in the future, as indicated by their recent exertions to water down the US CAFE legislation for 2017-2025 (Roland, 2011).

Previous regulations of local pollutants forced vehicle makers to adopt very similar solutions. In the case of $\mathrm{CO}_{2}$ emissions there is a rapidly expanding portfolio of technological solutions, which means that regulatory authorities should be careful in 
supporting any particular technological avenue. In fact, there are strong reasons, both from the perspective of efficiency (lowest cost) and in the interest of broad search (innovation-encouragement) to actively refrain from technology-specific forcing. A prime challenge in this respect is to establish relevant criteria that enable lifecycle comparisons, considering that increased electrification will reduce tailpipe $\mathrm{CO}_{2}$ emissions at the expense of increased emissions from vehicle production as well as from electric power generation (Schäfer et al, 2006).

The key role of regulation should be to set in place a credible and stable system of stepwise increasing standards, and on that basis encourage competition between firms as well as between technologies, but also support collaboration and information-sharing, for example regarding new standards and technical interfaces. National authorities can promote such an industrial dynamic if they devise general incentives for early introduction of low-emitting vehicles, without specifying any technologies used. This will encourage consumers to make $\mathrm{CO}_{2}$ emissions a key part of their purchasing decisions and stimulate competition among car makers to move more rapidly than the legally required levels.

The continual development of ICE-technologies in modern vehicles has been shadowed by the tendency to technological over-shooting, where improvements in efficiency are used for increases in convenience, comfort and weight, faster acceleration and higher top speed (Cuenot, 2009). Sustainable vehicles require a different mix of performance parameters, built around safety, convenience, efficiency and emissions. The critical issue 
is not technology. The critical issue is a long-term oriented, technology-neutral, innovation and competition driving policy, built around stepwise tightening of emissions and incentive levels. Previous examples of public efforts to reduce automotive emissions illustrate the forcing power of regulatory interventions, both in terms of technological innovation and rapid diffusion, provided they do not mandate new types of vehicle platforms. If the US emissions legislation in 1970 had been based on extrapolations of trends in the 1960s, California would still be suffering from noxious smog. The role of appropriate regulation for encouraging competitive dynamics and broad competition between firms and technologies is crucial when understanding future improvements trajectories and setting new standards.

\section{References}

ACEA, 2010. Overview of $\mathrm{CO}_{2}$-based Motor Vehicle Taxes in the EU. ACEA, April 20.

Anderson, P., Tushman, M.L., 1990. Technological discontinuities and dominant designs: A cyclical model of technological change. Administrative Science Quarterly 35, 604-633.

Ashley, S. 2011. Volvo to test flywheel-KERS hybrid cars. SAE International, July 12.

Bauner, D., 2007. Towards a sustainable automotive industry - experiences from the development of emission control systems. PhD dissertation, Stockholm: Royal Institute of Technology.

Berggren, C., Magnusson, T., Sushandoyo, D. 2009. Hybrids, diesel or both? The forgotten technological competition for sustainable solutions in the global automotive industry. International Journal of Automotive Technology and Management, 9(2), 148-173.

Christensen, C., 1992. Exploring the Limits of the Technology S-curve. Part I: Component Technologies. Production and Operations Management, 4, 334-357.

Clerides, S., Zachariadis, T. 2008. The effects of standards and fuel prices on automobile fuel economy: An international analysis. Energy Economics, 30, 2657-2672. 
Crank Motoring, 2010. Fiat's 900cc TwinAir two-cylinder engine debuts in the Cinquecento. July 20. http://www.crankmotoring.com/?p=2298

Cuenot, F., 2009. $\mathrm{CO}_{2}$ emissions from new cars and vehicle weight in Europe: How the EU regulation could have been avoided and how to reach it? Energy Policy, 37(10), 3832-3842.

DoE 2009: Advanced Combustion Engine R\&D: Goals, Strategies, and Top Accomplishments, US Department of Energy: Vehicle Technologies Program

Doucette, R.T., \& McCulloc, M.D. 2011.Modeling the $\mathrm{CO}_{2}$ emissions from battery electric vehicles given the power generation mixes of different countries. Energy Policy, 39, 803-811.

Dunbeck, P.B., Reitz, R.D., 2010. An Experimental Study of Dual Fueling with Gasoline Port Injection in a Single-Cylinder, Air-Cooled HSDI Diesel Generator. SAE paper 2010-01-0869.

EC, 1998. Directive 98/69 relating to measures to be taken against air pollution by emissions from motor vehicles and amending Council Directive 70/220/EEC. Official Journal 28.12.

EC, 2007. Regulation No 715/2007 on type approval of motor vehicles with respect to emissions from light passenger and commercial vehicles (Euro 5 and Euro 6). Official Journal 29.6.

EEA, European Environment Agency, 2010. Annual European Union greenhouse gas inventory 1990-2008 and inventory report 2010. Technical report, May 27.

Edwards, C. 2011. Personal communication, Sept 29; forthcoming work (2012).

EPA, Environmental Protection Agency, 2010. Light-Duty Vehicle Greenhouse Gas Emission Standards and Corporate Average Fuel Economy Standards for Model Years 2017-2025. Interim Joint Technical Assessment Report, Office of Transportation and Air Quality, September.

Greene, D. 2010. Why the Market for New Passenger Cars Generally Undervalues Fuel Economy. Joint Transport Research Centre Round Table 18-19 February 2010. OECD/-International Transport Forum, Paris

Fontaras, G., Samaras, Z., 2010. On the way to $130 \mathrm{~g} \mathrm{CO}_{2} / \mathrm{km}$ - Estimating the future characteristics of the average European passenger car. Energy Policy 38(4), 1826-1833.

Gerard, D., Lave, L.B., 2005. Implementing technology-forcing policies: The 1970 clean air act amendments and the introduction of advanced automotive emissions control in the Unites States. Technological Forecasting and Social Change, 72, 761-778. 
Hekkert, M.P., van den Hoed, R., 2006. Competing technologies and the struggle towards a new dominant design: The emergence of the hybrid vehicle at the expense of the fuel cell vehicle? Greener Management International 47, 29-43.

Henderson, R., Clark, K.B., 1990. Architectural innovation: The reconfiguration of existing product technologies and the failure of established firms. Administrative Science Quarterly 35, 9-30.

IEA. 2010 . World Energy Outlook. International Energy Agency. November 9.

Jaffe, A.B., Newell, R.G., Stavins, R.N., 2002. Environmental Policy and Technological Change. Environmental and Resource Economics, 22, 41-69.

Johansson, B., 2010. Partially Premixed Combustion, PPC, for high fuel efficiency engine operation. Presentation Lund University, Division of Combustion Sciences, of Technology, May 2010.

Kapp, D., 2010. Top powertrain technologies already driving the industry’s future. Automotive Engineering Online, April 14, 2010.

King, J (2007): The King review of low-carbon cars, HM Tresaruy

Knecht, W., 2008. Diesel engine development in view of reduced emission standards. Energy, 33, $264-271$.

Knight, B., 2010. Better Mileage now. Scientific American, 302(2), 50-55.

Kranz, R., 2009. Shift to electric steering brings parallel-parking assist to Ford. Automotive News, March 16.

Kromer, M.A., Bandivadekar, A., Evans, C., 2010. Long-term greenhouse gas emission and petroleum reduction goals: Evolutionary pathways for the light-duty vehicle sector. Energy, 35, 387-397.

Kurylko, D., 2010. Audi will add diesels to more vehicles. Automotive News, November 1.

Kågeson, P., 2009. Miljöbil på villovägar. (“Green cars on the road to nowhere”) Stockholm: SNS.

Lee, J., Veloso, F.M., Hounshell, D.A., Rubin, E.S., 2010. Forcing technological change: A case of automobile emissions control technology development in the US. Technovation, 30, 240-264.

Lewander, M., Johansson, B., Tunestal, P., Keeler, N., Milovanovic, N., Tullis, S., Bergstrand, P., 2009.

Evaluation of the Operating Range of Partially Premixed Combustion in a Multi Cylinder Heavy

Duty Engine with Extensive EGR. SAE paper 2009-01-1127.

Lilja, D., 2009. Snålast och dyrast. VW Polo Bluemotion. Teknikens Värld, 26. 
Magnusson, T \& Berggren, C.201. Entering an Era of Ferment - radical vs. incrementalist strategies in automotive powertrain development, Technology Analysis and Strategic Management, 23,3, 313330

Manente, V., Johansson, B., Tunestal, P., Cannella, W., 2010a. Effects of different type of gasoline fuels on heavy duty partially premixed combustion. SAE International Journal of Engines, 2(2), 71-88.

Manente, M., Johansson, B., Tunestal, P., 2010b. Gasoline Partially Premixed Combustion: High Efficiency, Low NOx and Low Soot by Using an Advanced Combustion Strategy and a Compression Ignition Engine. International Journal of Vehicle Design (in press).

Moran, T., 2010. 5-speed tranny? That's old news in mpg war. Automotive News, June 24.

Offer, G.J., Howey, D., Contestabile, M., Clague, R., Brandon, N.P., 2010. Comparative analysis of battery electric, hydrogen fuel cell and hybrid vehicles in a future sustainable road transport system. Energy Policy, 38, 24-29.

Pilkington, A., Dyerson, R., 2005. Gales of creative destruction and the opportunistic incumbent: The case of electric vehicles in California. Technology Analysis and Strategic Management 17(4), 391-408.

Ra, Y., Yun, J.E., Reitz, R.D., 2009. Parametric Study of Diesel Engine Operation with Gasoline. Combustion Science and Technology, 181(2), 350-378.

Roland, N. 2011. Detroit wins major plum in CAFE deal. Big pickups exempted in 54.5 mpg plan, Automotive News, August 1.

Scania, 2007. Interview with Greger Juhlin, Engineering manager in charge of emissions and performance, May 20.

Scania, 2008. Interview with Hasse Johansson, Vice President of R\&D, January 20.

Schoots, K., Kramer, G.J., van der Zwaan, B.C.C., 2010. Technology learning for fuel cells: An assessment of past and potential cost reductions, Energy Policy 38(6), 2887-2897.

Schäfer, A., Heywood, J.B., Weiss, M.A., 2006. Future fuel cell and internal combustion engine automobile technologies: A 25-year life cycle and fleet impact assessment. Energy 31, 2064-2087.

Shnayerson, M., 1996. The Car That Could. The Inside Story of GM's Revolutionary Electric Vehicle. Random House, New York.

Simmons, C. 2011. Euro 6 high performers. Scania World, 1/2011. 
Sperling, S.D., Gordon, D., 2009. Two billion cars. Oxford University Press, Oxford.

Stjerna, M., 2010. SM i snålast. Teknikens Värld, 7, 60-62.

Suppes, G.J., 2006. Roles of plug-in hybrid electric vehicles in the transition to the hydrogen economy. International Journal of Hydrogen Energy, 31(3), 353-360.

Tao, L., Garnsey, E., Probert, D., Ridgman, T., 2010. Innovation as response to emissions legislations: Revisiting the automotive catalytic converter at Johnson Matthey. R\&D Management, 40(2), 154167.

Taylor, A., 2008. Science Review of internal combustion engines. Energy Policy, 36, 4657-4667.

Thiel, C., Perujo, A., Mercier, A., 2010. Cost and $\mathrm{CO}_{2}$ aspects of future vehicle options in Europe under new energy policy scenarios. Energy Policy, 38, 7142-7151.

Transport \& Environment, 2007. Reducing $\mathrm{CO}_{2}$ emissions from new cars. 2006 progress report on the car industry's voluntary agreement. www.transportenvironment.org

Transport \& Environment, 2009. Reducing $\mathrm{CO}_{2}$ Emissions from New Cars: A Study of Major Car Manufacturers' Progress in 2008. September 2009.

Transport \& Environment, 2010. How clean are Europe's cars? An analysis of carmaker progress towards EU targets in 2009. November 2010.

Transport \& Environment, 2011. How clean are Europe's cars? An analysis of carmaker progress towards EU CO$~_{2}$ targets in 2010. September 2011.

Tzirakis, E., Pitsas, K., Zannikos, F., Stournas, S. 2006. Vehicle emissions and driving cycles: Comparison of the Athens driving cycle (ADC) with ECE-15 and European driving cycle (EDC), Global NEST Journal, 8, 3,282-290.

VCC, 2010a. Interview with Ulf Nordström, managing coordinator of the DRIVe program, April 21.

VCC, 2010b. Interview with Ulf Nordström and combustion researchers, October 21.

VCC, 2010c. Personal correspondence with P-Å Fröberg, May 5, Sophia Frykmer, November 19.

Zervas, E., 2010. Analysis of the $\mathrm{CO}_{2}$ emissions and of the other characteristics of the European market of new passenger cars. Energy Policy, 38, 5413-5425. 